\title{
ERRA TUM
}

Water, Air, and Soil Pollution 5 (1975) 195-205.

\section{COMPOSITIONAL CHANGES OF A FUEL OIL FROM AN OIL SPILL DUE TO NATURAL EXPOSURE}

\author{
RAYMOND N. YONG
}

William Scott Professor of Civil Engineering and Applied Mechanics Director, Soil Mechanics Research Laboratory, McGill University, Montreal, Canada

and

AMAR J. SETHI

Research Associate, Dept. of Civil Engineering and Applied Mechanics, McGill University, Montreal, Canada

The publishers wish to apologise to Dr Yong for the incorrect spelling of his name in the last issue. 